DOI: $10.20472 / B M .2015 .3 .1 .003$

\title{
PRIORITIZING STRATEGIC BUSINESS UNITS IN THE FACE OF INNOVATION PERFORMANCE: COMBINING FUZZY AHP AND BSC
}

\section{BEHROOZ NOORI}

\begin{abstract}
:
Large corporations may be composed of multiple strategic business units (SBUs), each of which is responsible for its own profitability. Innovation performance management of SBUs boosts corporation business results. In the present work, SBU ranking based on innovation performance was addressed. The contribution of the proposed model was threefold: (1) it proposed a fuzzy analytic hierarchy process (AHP) for SBU ranking with triangular fuzzy numbers; (2) it provided a comprehensive and systematic framework that combined balanced scorecard (BSC) and fuzzy AHP; and (3) it explored practical application and illustrated the efficacy of the procedures and algorithms. It used a real-world case study in a large steel manufacturing company to present the applicability of the system. Finding SBU priorities would help the corporations to develop strategies and policies to manage and improve SBU performance.
\end{abstract}

\section{Keywords:}

strategic business unit, innovation performance, SBU performance, balanced scorecard, fuzzy analytic hierarchy process, steel sector

JEL Classification: C44, L25, L21

\section{Authors:}

BEHROOZ NOORI, Department of Industrial Engineering, West Tehran Branch, Islamic Azad University, Tehran, Iran, Iran , Email: bnoori@gmail.com

\section{Citation:}

BEHROOZ NOORI (2015). Prioritizing strategic business units in the face of innovation performance: Combining fuzzy AHP and BSC. International Journal of Business and Management, Vol. III(1), pp. 36-56., 10.20472/BM.2015.3.1.003 


\section{Introduction}

Despite the advances in technology and innovation, many of companies do not measure or assess innovation performance and do not have an internal system to measure innovation performance (Hamel, 2006). In the current economic situation, innovation is a high strategic priority for most companies, and many see it as a strong contributor to growth. Yet, many also struggle to measure the performance of their innovation portfolios (Chan et al., 2008). Besides, corporations should seek sustainable innovation performance (Vandaele and Decouttere, 2012).

The Frascati manual stated that innovation can be an idea into the launching of a new or improved product, a new or improved process, or a new method (OECD, 1994). Dervitsiotis (2010) proposed key components of an organisation's innovation system. He presented an assessment framework for corporation's innovation excellence. Alegre et al. (2009) evaluated innovation by analysing the relationship between research and development $(R \& D)$ process, innovation performance, and organisational growth in the context of biotechnology corporations.

A key component in the success of corporations is the extent of their innovativeness. Innovativeness relates to the corporation's capacity to engage in innovation; that is, the introduction of new processes, products, or ideas in the organization. This capacity to innovate is among the most important factors that impact on business performance. It is through innovativeness that managers devise solutions to business problems and challenges, which provide the basis for the survival and success of the corporation well into the future. Innovativeness is one of the factors over which the management has considerable control. It is generally agreed that innovation contributes to business performance, relatively little is known about the drivers of innovativeness and how those drivers operate via innovativeness to collectively influence performance (Hult and Hurley, 2004). Moreover, little is known about the innovativeness ranking under different business units.

Certain types of innovations such as administrative innovations that improve internal operations may have no direct or immediate impact on the marketplace (Han et al., 1998). A critical part of the initiation stage is cultural "openness to the innovation" (Zaltman et al., 1973). Openness includes whether the members of an organization are willing to consider the adoption of an innovation or whether they are resistant to it. de Ven (1986) refers to this as the management of the organization's cultural attention in order to recognize the need for new ideas and action within the organization.

Much of the corporation's innovativeness hinges on the extent to which managers acquire and act on market intelligence. Organizations that act are responsive to markets. Organizations or SBUs without the capacity to innovate may invest time and resources in studying markets but are unable to translate this knowledge into practice (Hult and Hurley, 2004).

The adoption of innovation is generally intended to contribute to the performance or effectiveness of the corporation or SBU (Damanpour, 1991). SBU performance is defined here as the achievement of organizational goals related to profitability and 
growth in sales and markets share, as well as the accomplishment of general corporation strategic objectives. The resource-based view helps to explain how corporations derive competitive advantages by channeling resources into the development of new products, processes, and so forth. Innovation is a means for changing a SBU, whether as a response to changes that occurs in its internal or external environment or as a preemptive move taken to influence an environment. Because environments evolve, SBUs must adopt innovations over time and the most important innovations are those that allow the SBU to achieve some sort of competitive advantage, thereby contributing to its performance (Damanpour, 1991).

SBU ranking is an important issue for holding managers and CEOs, since it can be used in budget allocation, improvement management, right strategic alignment, and business performance improvement.

The BSC can be used as a framework for evaluation of innovation performance. Kaplan and Norton originated BSC in 1992. Since then BSC has been the subject of performance evaluation studies (Valderrama et al., 2009). It converts an organisation's vision into a comprehensive set of performance indicators, which creates a framework for a strategic measurement system.

In this study, BSC provided a framework for innovation performance evaluation. This work used a fuzzy AHP to prioritize SBUs in a well-known steel manufacturing company in Iran. The SBU with the highest priority weight was chosen as the best SBU regards its innovation capability. To determine the priority weights of the alternatives and simplify comparisons of BSC dimensions, criteria, and alternatives, MS Excel was utilized.

This paper is organized into five sections. The Section 2 was devoted to literature overview. In section 3, fuzzy AHP method was explained. In section 4, model implementation was presented. In section 5 , concluding remarks and discussions were specified.

\section{Literature review}

2.1. BSC and R\&D relationship

The BSC has four perspectives (i.e., learning and growth perspective, process perspective, customer perspective, and financial perspective) (Kaplan and Norton, 1993). The BSC is a strategic framework for performance measurement and strategy implementation. The BSC model links long-term objectives with short-term activities (Kaplan and Norton, 1996). Financial and non-financial criteria are just a part of BSC framework. The BSC provides infrastructure which translates strategy into a combined set of indicators that addresses long-term objectives, short-term activities and relevant feedbacks (Kaplan and Norton, 1996).

$R \& D$ is now a key part of company innovation system, and requires an integrated mechanism of measurement that monitors both financial and non-financial returns (Bigliardi and Dormio, 2010).

Several studies have investigated the relation between the BSC and R\&D. Sandstrom and Toivanen (2002) proposed a BSC framework for product 
development. They presented dimensions, objectives, and indicators of the BSC for R\&D domain. Cebeci and Sezerel (2008) used the BSC to develop a performance measurement model for R\&D department. The proposed model comprised thirteen important R\&D performance indicators based on the literature survey and expert opinions. Chen and Chen (2009) presented a framework for innovation performance evaluation. This framework proposed 24 indicators for innovation performance measurement and used 2-tuple fuzzy interval linguistic evaluation model to measure the innovation performance. In addition, Bigliardi and Dormio (2010) developed a general model of BSC for R\&D activities performance measurement. They composed BSC model by 54 indicators subdivided into the five perspectives. Further, Wang et al., (2010) proposed performance indicators of the R\&D department using the BSC structure. Moreover, Lazzarotti et al., (2011) suggested a model for R\&D performance measurement.

2.2. $B S C$ and $A H P$ integration

Integration of BSC and multi-criteria decision making techniques has been reviewed in the several studies. BSC, which describes perspectives of performance, does not determine perspective weights. Hence, Reisinger et al. (2003) presented an AHP method to prioritize the indicators of a BSC system for a European management-consulting firm. Searcy (2004) used AHP to calculate the relative weight of the performance perspectives regarding extended BSC for lean enterprises. Leung et al. (2006) used AHP and analytic network process (ANP) to simplify the BSC implementation. Additionally, Leung et al. (2006) illustrated how the AHP is applied when relationship between attributes may be implicitly evaluated. Chan (2006) proposed AHP-BSC model for hospital performance assessment. Sharma and Bhagwat (2007) and Varma et al. (2008) studied the integration of AHP and BSC in supply chain management. Moreover, Cebeci and Sezerel (2008) combined BSC with AHP in order to develop an approach to assess the performance of the R\&D departments. Jovanovic and Krivokapic (2008) used AHP to identify BSC key performance indicators. Huang et al. (2011) integrated AHP, delphi method, and BSC framework to prioritize performance indicators and strategies in a pharmaceutical firm. Bentes et al. (2012) combined BSC and AHP to perform a better performance evaluation of three organizational units within a telecommunications company. Other applications of the AHP method within a BSC system was gave emphasis on the development of a performance measurement system (e.g., Huang, 2009; Grigoroudis et al., 2012).

\subsection{Fuzzy AHP}

With regard to uncertainties and vagueness of a decision problem and excluding the disadvantages of the AHP, fuzzy AHP was used in this study. In the fuzzy AHP process, the pairwise comparisons in the judgment matrix are fuzzy numbers. The procedure calculates a corresponding set of scores and determines one composite score that is the average of these fuzzy scores (Kahraman et al., 2004). Kahraman et al. (2004) used fuzzy AHP to compare catering firms. Haghighi et al. (2010) presented main characteristics, advantages, and disadvantages of different fuzzy 
AHP methods. Kilincci and Onal (2011) presented a fuzzy AHP to select the best supplier providing the most customer satisfaction index for a washing machine company. Buyukozkan et al. (2011) is another work about Fuzzy AHP. This work evaluated the proposed service quality framework in the healthcare sector in Turkey. Cho et al. (2012) developed performance measurement framework based on the extent fuzzy AHP for a hotel supply chain. Kutlu and Ekmekcioglu (2012) proposed an integrated approach, combining fuzzy AHP and Fuzzy TOPSIS, to rank failure modes. Furthermore, Zhu and Lei (2012) proposed fuzzy AHP in the evaluation of the independent innovation capability of the businesses. They presented ten indicators for innovation evaluation.

\subsection{BSC and Fuzzy AHP}

Integration of BSC and fuzzy AHP has been also investigated. Lee et al. (2008) suggested a method to compute performance priority weightings of information technology departments based on BSC and fuzzy AHP integration. They provided guidance to IT department managers regarding performance evaluation and strategies for improving department performance. Wang and Xia (2009) constructed a BSC framework based on knowledge management and the fuzzy AHP for evaluating a software company. Cebeci (2009) proposed a fuzzy AHP model for comparison of ERP solutions and vendors for textile companies and also presented related key performance indicators based on BSC framework. Furthermore, Wu, Tzeng and Chen (2009) have been conducted a performance analysis on three banks using a fuzzy MCDM methodology based on the BSC perspectives. The fuzzy AHP and the three MCDM analytical methods (i.e., SAW, TOPSIS, and VIKOR) were employed in the performance analysis for computing the fuzzy weights of the criteria, ranking the banking performance, and improving the gaps of the three banks, respectively. Cho and Lee (2011) proposed a model based on BSC and fuzzy AHP for evaluation and selection of business processes for BPM. This work has considered decision maker confidence and the degree of satisfaction of the judgment in the fuzzy AHP model. Kunz and Schaaf (2011) presented a general definition of an indicator system for each perspective in a BSC in a clinical application and defined a utility function. Amiran et al. (2011) used fuzzy AHP and Fuzzy TOPSIS for evaluating steel industry performance based on BSC. Su, Hung and Tzeng (2011) used fuzzy AHP and BSC in the mobile industry. Additionally, Wang, Zhang and Zeng (2012) proposed a method based on the Fuzzy AHP and BSC for evaluating performance of Third-Party Logistics (TPL) enterprises.

Therefore, integrating of fuzzy AHP, BSC and innovation performance evaluation of SBUs are not currently seen in the literature. In other words, up to now very few references have been found in the literature to the SBU innovation performance modeling. Therefore, this study adopted the BSC to develop an innovation evaluation system for SBU ranking in a steel manufacturing company.

\section{Research method}




\subsection{AHP and Fuzzy AHP}

AHP is a systematic procedure to solve multi-criterion decision-making problems. It includes both subjective and objective evaluation measures, offering a useful hierarchical procedure to control the consistency of the evaluation measures and alternatives preferred by decision makers to reduce bias in decision-making process (Kilincci \& Onal, 2011). In structuring of the decision problem into a hierarchical model, problem is defined, which is the most innovative business unit selection, objective is identified, and attributes that must be satisfied to objective are recognized. Objective is at first level, criteria is at second level, attributes are at third level, and decision alternatives are at fourth level in hierarchical structure of the problem. In making pair-wise comparisons and obtaining the judgment matrix, the elements at a particular level are compared using nine-point numerical scale to define how much more an element is important than other. If $A$ and $B$ are the elements to compare, " 1 " defines that $A$ and $B$ are equal importance, and " 9 " defines that $A$ is extreme importance. All pair-wise comparisons are given in a judgment matrix. Next step is to determine the local weights and consistency of comparisons. Local weights of the elements are calculated from the judgment matrix using eigenvector method. As the comparisons in the matrix are made subjectively, consistency ratio can be computed. If the ratio is less than 0.1 human judgments is acceptable. In last step, local weights at various levels are aggregated to obtain final weight of alternatives. The final weights represent the rating of the alternatives in achieving the aim of the multi-criterion decision-making problem.

Although AHP has been widely used to solve the multi-criterion decision-making problems, its most important disadvantage is that it uses a scale of one to nine which cannot handle uncertainty decisions in comparison of the attributes. All comparisons during AHP implementation may not include a certainty therefore the decision maker needs more than nine-point scale to describe the uncertainty. In this condition, linguistic variables and triangular fuzzy numbers can be used to decide the priority of one decision variable over other. Synthetic extent analysis method is used to decide the final priority weights based on triangular fuzzy numbers and so-called as fuzzy extended AHP (Chan \& Kumar, 2007).

The fuzzy extension of AHP to efficiently handle the fuzziness in the decision process to select the best business unit by using both qualitative and quantitative data in the multi-attribute decision-making problems. In this approach triangular fuzzy numbers are used in replace of nine-point of scale in traditional AHP and then the synthetic extent value of the pair-wise comparison is calculated by using the extent analysis method. After the weight vectors are decided and normalized, and normalized weight vectors are determined, the final priority weights of the alternatives are computed using the different weights of criteria and attributes. As a result, the alternative with highest weight is selected as the best business unit. 


\subsection{Fuzzy AHP with triangular fuzzy numbers}

Zadeh proposed fuzzy logic to resolve ambiguous and vague information. An object in a fuzzy set has grade of membership in [0,1] (Kilincci and Onal, 2011). The proposed fuzzy AHP model utilized triangular fuzzy numbers in pairwise judgments and evaluation matrixes. A triangular fuzzy number $(\widetilde{M})$ is depicted in Fig. 1. A triangular fuzzy number is represented as $(l, m, u)$. The parameters $l, m$, and $u$ identify the smallest possible value, the most promising value, and the largest possible value that illustrate a fuzzy event (Kahraman et al., 2004).

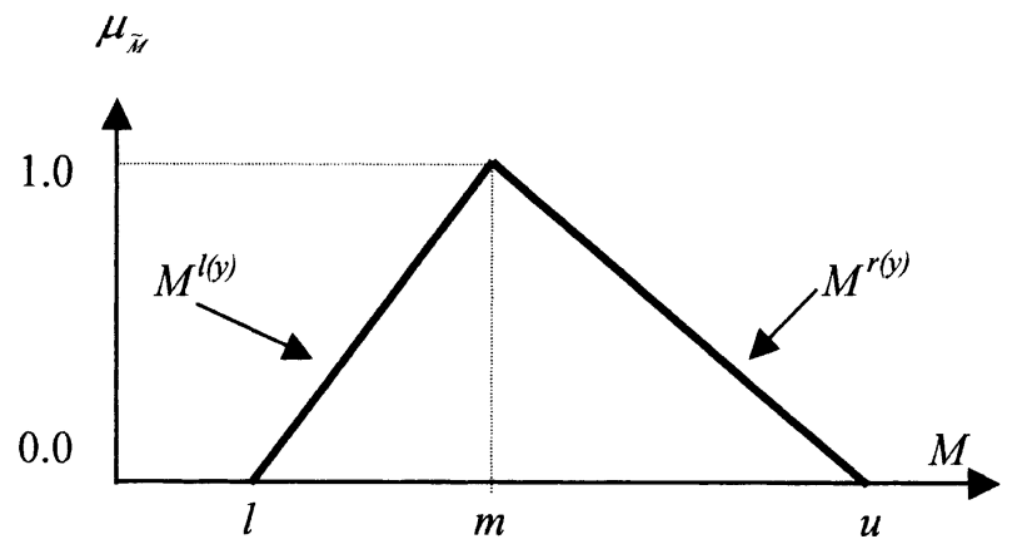

Fig. 1. A triangular fuzzy number, $\widetilde{M}$ (Source: Kahraman et al., 2004)

Triangular fuzzy number membership function can be described as (Kahraman et al., 2004);

$\mu_{\widetilde{M}}=\left\{\begin{array}{c}0, x<1, \\ \frac{x-l}{m-l}, l \leq x \leq m, \\ \frac{u-x}{u-m}, m \leq x \leq u \\ 0, x>u\end{array}\right.$

$\widetilde{M}=\left(M^{l(y)}, M^{r(y)}=(l+(m-l) y, u+(m-u) y), y \in[0,1]\right.$,

According to the Chang's (1992) method, each object is taken and extent analysis for each goal, $g_{i}$, is done respectively. Therefore, $m$ extent analysis values for each object can be achieved, with the following signs:

$M_{g_{i}}^{1}, M_{g_{i}, \ldots,}^{2}, M_{g_{i},}^{m}, \quad \mathrm{i}=1,2, \ldots, \mathrm{n}$

where all the $M_{g_{i}}^{j}(j=1, \ldots, m)$ are triangular fuzzy numbers.

The steps of Chang's extent method can be presented as in the following (Chang, 1996; Kahraman et al., 2004):

(1) The value of fuzzy synthetic extent with respect to ith object is determined as 
$S_{i}=\sum_{j=1}^{m} M_{g_{i}}^{j} \otimes\left[\sum_{i=1}^{n} \sum_{j=1}^{m} M_{g_{i}}^{j}\right]$

To calculate $\sum_{j=1}^{m} M_{g_{i}}^{j}$, consider the fuzzy addition operation of $m$ extent analysis values for a particular matrix such that

$\sum_{j=1}^{m} M_{g_{i}}^{j}=\left(\sum_{j=1}^{m} l_{j}, \sum_{j=1}^{m} m_{j}, \sum_{j=1}^{m} u_{j}\right)$

and to calculate $\left[\sum_{i=1}^{n} \sum_{j=1}^{m} M_{g_{i}}^{j}\right]^{-1}$, consider the fuzzy addition operation of $M_{g_{i}}^{j}(j=$ $1,2, \ldots, m)$ values such that

$\sum_{i=1}^{n} \sum_{j=1}^{m} M_{g_{i}}^{j}=\left(\sum_{i=1}^{n} l_{i}, \sum_{i=1}^{n} m_{i}, \sum_{i=1}^{n} u_{i}\right)$

and then obtain the inverse of the vector in Eq. (6) such that

$\left[\sum_{i=1}^{n} \sum_{j=1}^{m} M_{g_{i}}^{j}\right]^{-1}=\left(\frac{1}{\sum_{i=1}^{n} u_{i}}, \frac{1}{\sum_{i=1}^{n} m_{i}}, \frac{1}{\sum_{i=1}^{n} l_{i}}\right)$

(2) The degree of possibility or probability of $M_{2}=\left(l_{2}, m_{2}, u_{2}\right) \geq M_{1}=\left(l_{1}, m_{1}, u_{1}\right)$ is defined as

$V\left(M_{2} \geq M_{1}\right)=\sup _{y \geq x}\left[\min \left(\mu_{M_{1}}(x), \mu_{M_{2}}(y)\right]\right.$

sup represents supermom (i.e., the least upper bond of a set) and when a pair $(x, y)$ exits such that $y \geq x$ and $\mu_{M 1}(x)=\mu_{M 2}(y)$, then we have $V\left(M_{2} \geq M_{1}\right)=1$. It can be equivalently expressed as follows:

$V\left(M_{2} \geq M_{1}\right)=\operatorname{hgt}\left(M_{1} \cap M_{2}\right)=\mu_{M 2}(d)$

Where hit is the height of fuzzy numbers on the intersection of M1 and M2 and $d$ is $d$ is the ordinate of the highest intersection point $D$ between $M 1$ and $M 2$ (Fig. 2). To compare $M 1$ and $M 2$, both values of $V(M 1 \geq M 2)$ and $V(M 2 \geq$ M1) are required and essential. Eqs. (8) and (10) are equal.

$V\left(M_{2} \geq M_{1}\right)=\operatorname{hgt}(\mathrm{M} 1 \cap \mathrm{M} 2)=\left\{\begin{array}{c}1, \quad \text { if } m_{2} \geq m_{1}, \\ \frac{l_{1}-u_{2}}{\left(m_{2}-u_{2}\right)-\left(m_{1}-l_{1}\right)}, \text { otherise, }\end{array}\right.$ 


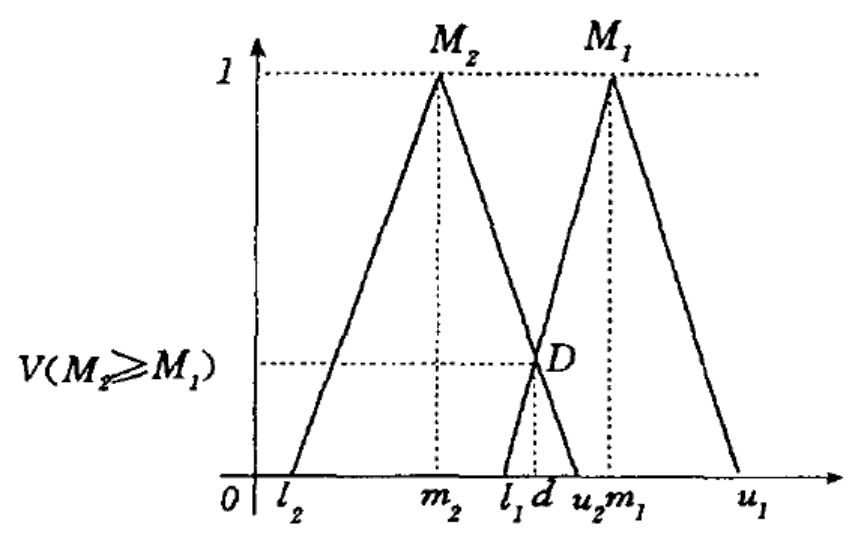

Fig. 2. The intersection between $M_{1}$ and $M_{2}$ (Source: Chang, 1996)

(3) The degree of possibility for a fuzzy number to be greater than $k$ fuzzy numbers $M_{i}(i=1,2, \ldots, k)$ can be given by the use of the operations max and min and can be shown by

$V\left(M \geq M_{1}, M_{2}, \ldots, M_{k}\right)=V\left(M \geq M_{1}\right)$ and $\left(M \geq M_{2}\right)$

and $\ldots$ and $\left(M \geq M_{k}\right)=\min V\left(M \geq M_{i}\right), i=1,2,3, \ldots, k$.

Assume that $d^{\prime}\left(A_{i}\right)$ is possibility for $M_{i}$ to be greater than other fuzzy numbers $\left(M_{K}\right)$.

$d^{\prime}\left(A_{i}\right)=\min V\left(M_{i} \geq M_{K}\right)$

For $k=1,2, \ldots, n ; k \neq i$, and $k$ is the number of criteria. Then the weight vector is specified by

$W^{\prime}=\left(d\left(A_{1}\right), d\left(A_{2}\right), \ldots, d\left(A_{n}\right)\right)^{T}$,

where $A_{i}(i=1,2, \ldots, n)$ are $n$ elements or decision alternatives.

(4) Via normalization, the normalized weight vectors are

$\mathrm{W}=\left[\frac{\mathrm{d} \prime\left(\mathrm{A}_{1}\right)}{\sum_{\mathrm{i}=1}^{\mathrm{n}} \mathrm{d} \prime\left(\mathrm{A}_{1}\right)}, \frac{\mathrm{d} \prime\left(\mathrm{A}_{2}\right)}{\sum_{\mathrm{i}=1}^{\mathrm{n}} \mathrm{d} \prime\left(\mathrm{A}_{2}\right)}, \ldots, \frac{\mathrm{d} \prime\left(\mathrm{A}_{\mathrm{n}}\right)}{\sum_{\mathrm{i}=1}^{\mathrm{n}} \mathrm{d} \prime\left(\mathrm{A}_{\mathrm{n}}\right)}\right]^{\mathrm{T}}$

To allow the values in the vector to be analogous to weights defined from the AHP type methods, the vector $W$ is normalized (Tang and Beynon, 2005). Where $W$ is a non-fuzzy number. This makes the priority weights of one alternative over another.

\section{Illustrative Example}

In SBU ranking problem, the relative importance of different decision criteria involved a high degree of subjective judgment and individual preferences. The linguistic assessment of human feelings and judgments were vague and it was not reasonable to represent them in terms of precise numbers. Therefore, triangular fuzzy numbers were used in this problem to decide the priority of one decision variable over another. Then synthetic extent analysis method was used to decide the final priority weights based on triangular fuzzy numbers and so-called as fuzzy AHP. In the following subsections, the main steps of the method will be explained in detail. 


\subsection{Definition of Criteria}

First the goal of the decision-making problem has been defined which was "selection of the most innovative SBU". In the steel sector, a lot of criteria should be considered because the competition is really high. By integration the attributes identified by R\&D and product development experts and other attributes which have been used in the literature (e.g., Lazzarotti, Manzini, and Mari, 2011; Valderrama, Mendigorri and Bordoy, 2009; Bigliardi and Dormio, 2010; Wang, Lin, and Huang, 2010), the criteria were defined. Innovation BSC framework and the criteria were shown in Fig. 5.

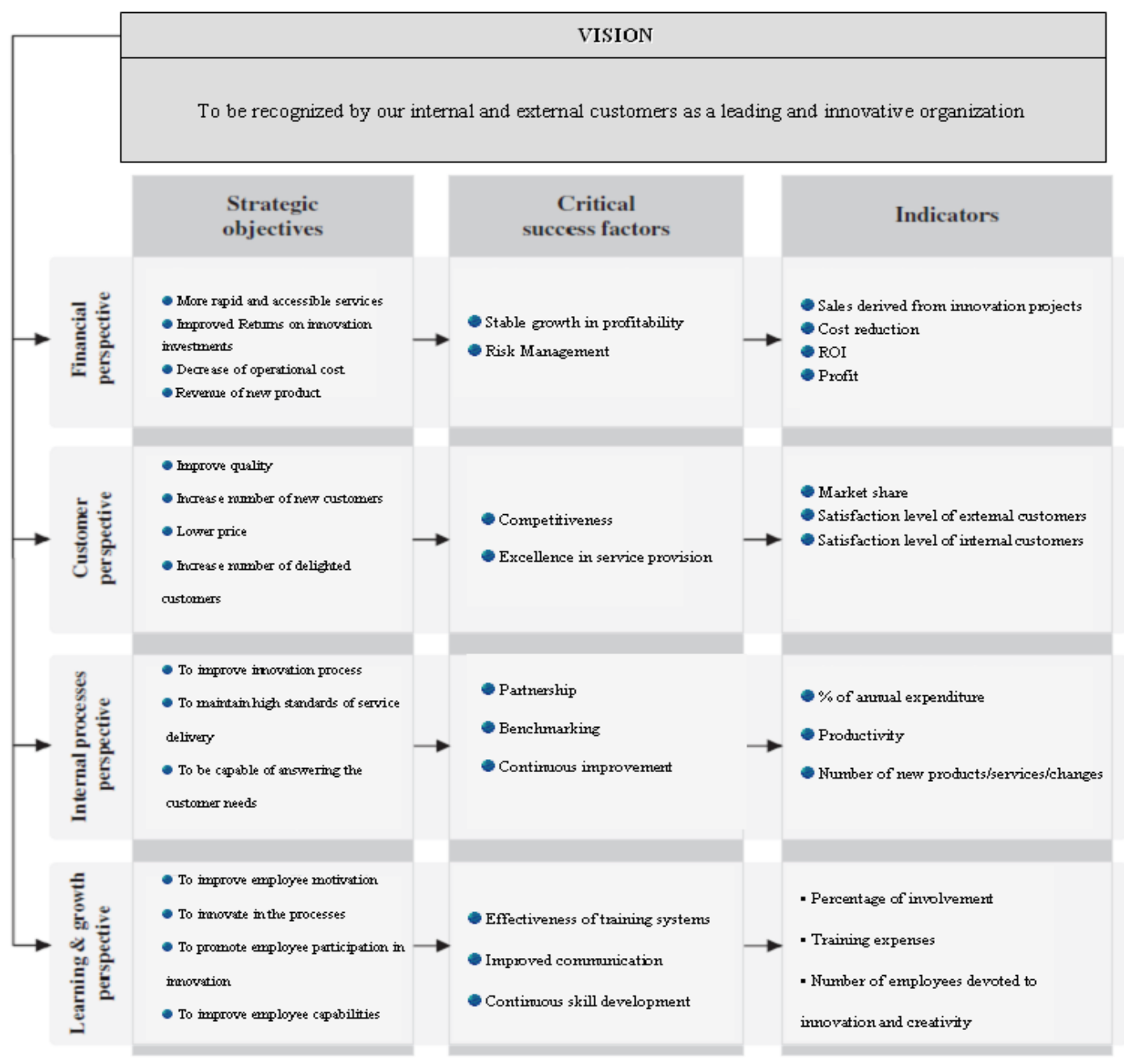

Fig. 3. Innovation BSC framework for each SBU

The hierarchy of the problem was built. Fig. 6 showed four levels of the problem hierarchy. The first level of the hierarchy specified the goal of the problem which was selection of the most innovative SBU. The second level of the hierarchy was organized under four categories, which were financial perspective, customer perspective, process perspective, and learning perspective. At the third level, BSC 
dimensions were separated into criteria that may influence the unit's choice. Finally, the bottom level of the hierarchy specified the three alternative SBUs.

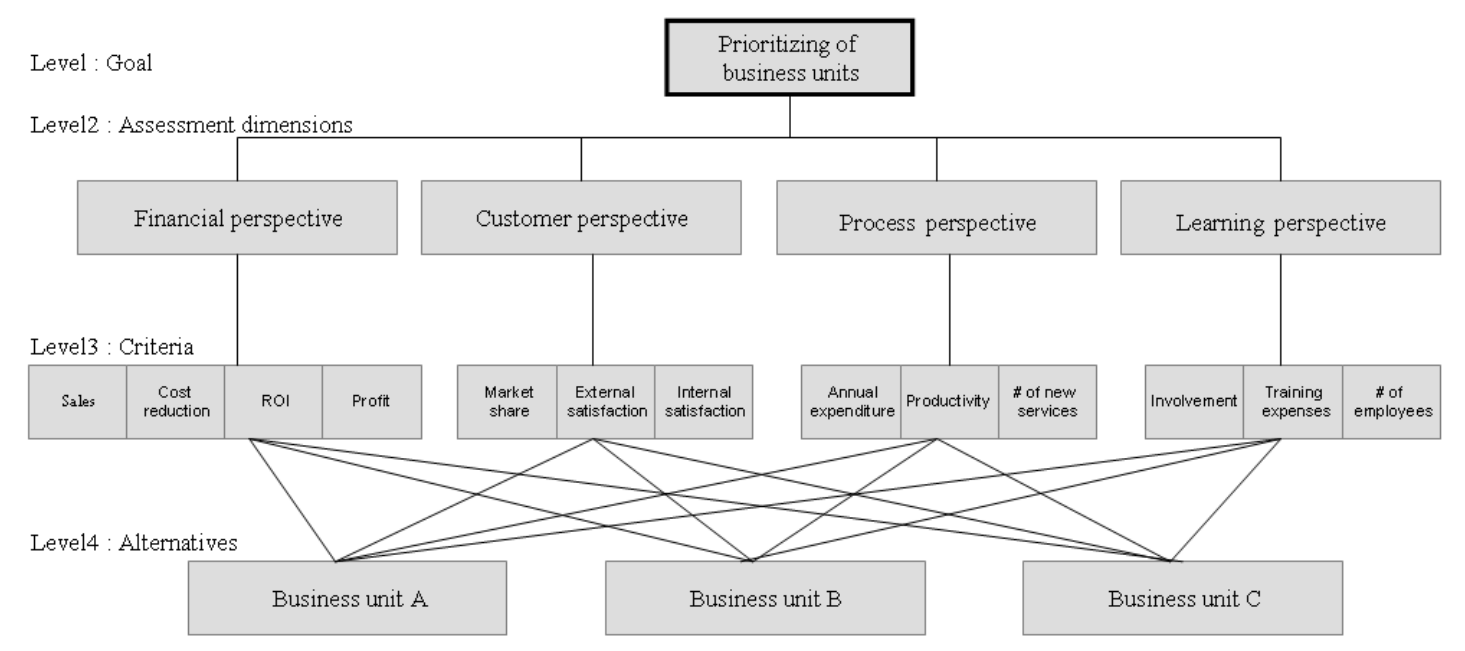

Fig. 4. Hierarchy structure for SBU selection

4.2. Computation the weights of the BSC dimensions, criteria and alternatives

BSC dimensions, criteria, and alternative are elements of the fuzzy AHP model. The questionnaires facilitated the finding of pair-wise comparison. Attribute preference over another was selected by the experience of experts. First, an expert compared the BSC dimensions with respect to the main goal; then the expert compared the criteria with respect to the BSC dimensions. At the end, the expert compared the SBUs with respect to each criterion. The expert used the linguistic variables to make the pair-wise comparison. Then the linguistic variables were changed to triangular fuzzy numbers. Table 1 illustrates the linguistic variables and their corresponding triangular fuzzy numbers.

Table 1. The linguistic variables and their corresponding fuzzy numbers.
Equally preferred (EP)
$(1,1,1)$
Weakly preferred (WP)
Fairly strongly preferred (FSP) $(3 / 2,2,5 / 2)$
Very strongly preferred (VSP) $(5 / 2,3,7 / 2)$
Absolutely preferred (AP)
$(7 / 2,4,9 / 2)$

As an example, the calculation of the priority weights of the BSC dimensions will be explained in detail below. By using the values in Table 1, the linguistic variables in the comparison matrix were changed to triangular fuzzy numbers. The fuzzy evaluation matrix can be seen in Table 3 . 
Table 2. The fuzzy evaluation matrix with respect to the goal with linguistic variables.

$\begin{array}{lcccc}\text { Financial } & \begin{array}{c}\text { Financial } \\ \text { perspective }\end{array} & \begin{array}{c}\text { Customer } \\ \text { perspective }\end{array} & \begin{array}{c}\text { Process } \\ \text { perspective }\end{array} & \begin{array}{c}\text { Learning } \\ \text { perspective }\end{array} \\ \begin{array}{l}\text { perspective } \\ \text { Customer } \\ \text { perspective }\end{array} & \text { WP } & \text { WP } & \\ \begin{array}{l}\text { Process } \\ \text { perspective }\end{array} & & \text { FSP } & \text { FSP } \\ \begin{array}{l}\text { Learning } \\ \text { perspective }\end{array} & \text { WP } & & \text { FSP } \\ \end{array}$

Table 3. The fuzzy evaluation matrix

$\begin{array}{lcccc} & \begin{array}{c}\text { Financial } \\ \text { perspective }\end{array} & \begin{array}{c}\text { Customer } \\ \text { perspective }\end{array} & \begin{array}{c}\text { Process } \\ \text { perspective }\end{array} & \begin{array}{c}\text { Learning } \\ \text { perspective }\end{array} \\ \begin{array}{l}\text { Financial } \\ \text { perspective }\end{array} & (1,1,1) & (2 / 3,1,3 / 2) & (2 / 3,1,3 / 2) & (2 / 3,1,3 / 2) \\ \begin{array}{l}\text { Customer } \\ \text { perspective }\end{array} & (2 / 3,1,3 / 2) & (1,1,1) & (2 / 5,1 / 2,2 / 3) & (3 / 2,2,5 / 2) \\ \begin{array}{l}\text { Process } \\ \text { perspective }\end{array} & (2 / 3,1,3 / 2) & (3 / 2,2,5 / 2) & (1,1,1) & (3 / 2,2,5 / 2) \\ \begin{array}{l}\text { Learning } \\ \text { perspective }\end{array} & (2 / 3,1,3 / 2) & (2 / 5,1 / 2,2 / 3) & (2 / 5,1 / 2,2 / 3) & (1,1,1)\end{array}$

In order to determine the priority weights of the BSC dimensions, first the fuzzy values of the dimensions were computed. The different values of fuzzy numbers of the four different BSC dimensions were denoted by $S_{f}, S_{C}, S_{\mathrm{Pr}}, S_{l r}$. F denotes financial perspective, $\mathrm{C}$ denotes customer perspective, pr illustrates process perspective, and Ir demonstrates learning perspective. Then, by applying Eq. (4), we have

$$
\begin{aligned}
& S_{f}=(3,4,5.5) \otimes(1 / 10.4 .17,1 / 13.5,1 / 17.67)=(0.17,0.3,0.53) \\
& S_{C}=(4.67,6,7.5) \otimes( \\
& 1 / 10.4 .17,1 / 13.5,1 / 17.67)=(0.28,0.48,0.75) \\
& S p r=(2.73,3.5,4.67) \otimes( \\
& 1 / 10.4 .17,1 / 13.5,1 / 17.67)=(0.16,0.28,0.47)
\end{aligned}
$$


$S_{l r}=(2.73,3.5,4.67) \otimes($

$1 / 10.4 .17,1 / 13.5,1 / 17.67)=(0.16,0.28,0.47)$

Then, the degree of possibility of $S_{i}$ over $S_{i}(i \neq j)$ was calculated. Using Eq. (10), $V\left(S_{f} \geq S_{C}\right)=\frac{(0.28-0.53)}{(0.30-0.53)-(0.48-0.28)}=0.58$

$V\left(S_{f} \geq S_{p r}\right)=1$

$V\left(S_{f} \geq S_{l r}\right)=1$

$V\left(S_{c} \geq S_{f}\right)=1$

$V\left(S_{c} \geq S_{p r}\right)=1$

$V\left(S_{c} \geq S_{l r}\right)=1$

$V\left(S_{p r} \geq S_{f}\right)=\frac{(0.17-0.47)}{(0.28-0.47)-(0.30-0.17)}=0.94$

$V\left(S_{p r} \geq S_{c}\right)=\frac{(0.28-0.47)}{(0.28-0.47)-(0.48-0.28)}=0.48$

$V\left(S_{p r} \geq S_{l r}\right)=1$

$V\left(S_{l r} \geq S_{f}\right)=\frac{(0.17-0.47)}{(0.28-0.47)-(0.30-0.17)}=0.94$

$V\left(S_{l r} \geq S_{c}\right)=\frac{(0.28-0.47)}{(0.28-0.47)-(0.48-0.28)}=0.48$

$V\left(S_{l r} \geq S_{p r}\right)=1$

Finally, by using Eq. (12), we obtain:

$d(f)=\min (0.58,1,1)=0.58$

$d(c)=\min (1,1,1)=1$

$d(p r)=\min (0.94,0.48,1)=0.48$

$d(I r)=\min (0.94,0.48,1)=0.48$

Consequently, the weight vector was obtained as $W^{\prime}=(0.58,1,0.48,0.48)$. After normalization process by Eq. (14), the normalized weight vector of the BSC dimensions was given to be $W=(0.23,0.39,0.19,0.19)^{\top}$.

The same computations were applied to the other pairwise comparison matrices and the priority weights of each element were calculated. The priority weights of each element can be found in Table 4.

Table 4. Priority vectors for the decision hierarchy. 


\begin{tabular}{|c|c|c|c|c|c|}
\hline $\begin{array}{l}\text { Variables in } \\
\text { level } 1\end{array}$ & $\begin{array}{l}\text { Level } 1 \\
\text { priorities }\end{array}$ & Variables in level 2 & $\begin{array}{c}\text { Level } 2 \\
\text { prioritie } \\
\mathbf{s} \\
\end{array}$ & $\begin{array}{l}\text { Variables in } \\
\text { level } 3\end{array}$ & $\begin{array}{c}\text { Level } 3 \\
\text { priorities }\end{array}$ \\
\hline \multirow[t]{12}{*}{$\begin{array}{l}\text { Financial } \\
\text { perspective }\end{array}$} & 0.23 & Sales & 0.24 & $S B \cup A$ & 0.37 \\
\hline & & & & SBU B & 0.43 \\
\hline & & & & $\mathrm{SBU} C$ & 0.20 \\
\hline & & Cost reduction & 0.34 & $\mathrm{SBU} A$ & 0.58 \\
\hline & & & & SBU B & 0.42 \\
\hline & & & & $\mathrm{SBU} C$ & 0 \\
\hline & & ROI & 0.17 & $\mathrm{SBU} A$ & 0.45 \\
\hline & & & & SBU B & 0.33 \\
\hline & & & & $\mathrm{SBU} C$ & 0.22 \\
\hline & & Profit & 0.25 & $\mathrm{SBU} A$ & 0.45 \\
\hline & & & & SBU B & 0.22 \\
\hline & & & & SBU C & 0.33 \\
\hline \multirow[t]{9}{*}{$\begin{array}{l}\text { Customer } \\
\text { perspective }\end{array}$} & 0.39 & Market Share & 0.37 & $\mathrm{SBU} A$ & 0.38 \\
\hline & & & & $\mathrm{SBU} B$ & 0.38 \\
\hline & & & & SBU C & 0.24 \\
\hline & & $\begin{array}{l}\text { Satisfaction level of } \\
\text { external customers }\end{array}$ & 0.43 & $\mathrm{SBU} A$ & 0.38 \\
\hline & & & & $\mathrm{SBU} B$ & 0.38 \\
\hline & & & & SBU C & 0.24 \\
\hline & & $\begin{array}{l}\text { Satisfaction level of } \\
\text { internal customers }\end{array}$ & 0.20 & $\mathrm{SBU} A$ & 0.37 \\
\hline & & & & SBU B & 0.37 \\
\hline & & & & $\mathrm{SBU} C$ & 0.26 \\
\hline \multirow[t]{9}{*}{$\begin{array}{l}\text { Process } \\
\text { perspective }\end{array}$} & 0.19 & $\begin{array}{l}\% \text { annual } \\
\text { expenditure in R\&D }\end{array}$ & 0.58 & $\mathrm{SBU} A$ & 0.45 \\
\hline & & & & $S B \cup B$ & 0.22 \\
\hline & & & & SBU C & 0.33 \\
\hline & & Productivity & 0.42 & $\mathrm{SBU} A$ & 0.45 \\
\hline & & & & SBU B & 0.22 \\
\hline & & & & SBU C & 0.33 \\
\hline & & $\begin{array}{l}\text { Number of new (or } \\
\text { improved) } \\
\text { products/services }\end{array}$ & 0 & $\mathrm{SBU} A$ & 0.58 \\
\hline & & & & SBU B & 0.42 \\
\hline & & & & $\mathrm{SBU} C$ & 0 \\
\hline \multirow[t]{3}{*}{$\begin{array}{l}\text { Learning } \\
\text { perspective }\end{array}$} & 0.19 & $\begin{array}{l}\text { Degree of } \\
\text { involvement }\end{array}$ & 0.31 & $S B \cup A$ & 0.38 \\
\hline & & & & SBU B & 0.38 \\
\hline & & & & SBU C & 0.24 \\
\hline
\end{tabular}




\begin{tabular}{|c|c|c|c|c|c|}
\hline $\begin{array}{l}\text { Variables in } \\
\text { level } 1\end{array}$ & $\begin{array}{c}\text { Level } 1 \\
\text { priorities }\end{array}$ & Variables in level 2 & $\begin{array}{c}\text { Level } 2 \\
\text { prioritie } \\
\text { s }\end{array}$ & $\begin{array}{c}\text { Variables in } \\
\text { level } 3\end{array}$ & $\begin{array}{c}\text { Level } 3 \\
\text { priorities }\end{array}$ \\
\hline & & Training expenses & 0.43 & SBU A & 0.37 \\
\hline & & & & SBU B & 0.43 \\
\hline & & & & SBU C & 0.20 \\
\hline & & $\begin{array}{l}\text { Number of } \\
\text { employees }\end{array}$ & 0.25 & SBU A & 0.37 \\
\hline & & & & SBU B & 0.43 \\
\hline & & & & SBU C & 0.20 \\
\hline
\end{tabular}

\subsection{Computation the overall score of each SBU and finding the best SBU}

In this step, the BSC dimensions and criteria priority weights were combined to compute priority weights of the alternative SBUs. In Table 5, each column of the matrix multiplied by the priority weight at the top of the column and then those values added up for each row. At the end, the priority weights of the alternatives were computed.

Table 5. Financial criteria.

\begin{tabular}{lccccc} 
& Sales & $\begin{array}{c}\text { Cost } \\
\text { reduction }\end{array}$ & ROI & Profit & $\begin{array}{c}\text { Alternative priority } \\
\text { weight }\end{array}$ \\
\cline { 1 - 4 } Weight & 0.24 & 0.34 & 0.17 & 0.25 & \\
\cline { 1 - 4 } Alternatives & & & & & \\
SBU A & 0.37 & 0.58 & 0.45 & 0.45 & 0.475 \\
SBU B & 0.43 & 0.42 & 0.22 & 0.22 & 0.3384 \\
SBU C & 0.20 & 0 & 0.33 & 0.33 & 0.1866
\end{tabular}

The same computations have been used to the other criteria of customer perspective, process perspective, and learning perspective, and the priority weights of the alternatives with respect to customer perspective, process perspective, and learning perspective have been computed. The priority weights were shown in Table 6, Table 7, and Table 8.

Table 6. Customer criteria.

\begin{tabular}{lcccc} 
& $\begin{array}{c}\text { Market } \\
\text { share satisfaction }\end{array}$ & $\begin{array}{c}\text { External } \\
\text { Internal }\end{array}$ & $\begin{array}{c}\text { Alternative } \\
\text { priority } \\
\text { weight }\end{array}$ \\
\cline { 1 - 4 } Weight & 0.37 & 0.43 & 0.20 & \\
\cline { 1 - 3 } Alternative & & & & \\
SBU A & 0.38 & 0.38 & 0.37 & 0.378 \\
SBU B & 0.38 & 0.38 & 0.37 & 0.378 \\
SBU C & 0.24 & 0.24 & 0.26 & 0.244
\end{tabular}


Table 7. Process criteria.

\begin{tabular}{lcccc} 
& $\begin{array}{c}\text { Expenditur } \\
\text { e }\end{array}$ & $\begin{array}{c}\text { Productivit } \\
\text { y }\end{array}$ & $\begin{array}{c}\text { Number } \\
\text { of } \\
\text { changes }\end{array}$ & $\begin{array}{c}\text { Alternative } \\
\text { priority } \\
\text { weight }\end{array}$ \\
\hline Weight & 0.58 & 0.42 & 0 & \\
Alternative & & & & \\
SBU A & 0.45 & 0.45 & 0.58 & 0.45 \\
SBU B & 0.22 & 0.22 & 0.42 & 0.22 \\
SBU C & 0.33 & 0.33 & 0 & 0.33
\end{tabular}

Table 8. Learning criteria.

\begin{tabular}{lcccc} 
& $\begin{array}{c}\text { Involveme } \\
\mathrm{nt}\end{array}$ & $\begin{array}{c}\text { Training } \\
\text { expenses }\end{array}$ & $\begin{array}{c}\text { Number } \\
\text { of } \\
\text { employee } \\
\text { s }\end{array}$ & $\begin{array}{c}\text { Alternative } \\
\text { priority } \\
\text { weight }\end{array}$ \\
\cline { 1 - 3 } Weight & 0.31 & 0.43 & 0.25 & \\
\cline { 1 - 3 } Alternatives & & & & \\
SBU A & 0.48 & 0.37 & 0.37 & 0.4004 \\
SBU B & 0.48 & 0.43 & 0.43 & 0.4412 \\
SBU C & 0.04 & 0.20 & 0.20 & 0.1484
\end{tabular}

At the end, the priority weights of the SBUs with respect to the BSC dimensions were obtained and the weights of the alternatives were calculated. The priority weights of the SBUs are shown in Table 9. In order to simplify the fuzzy AHP calculations, A program based on the Ms Excel was prepared.

Table 9. SBU priority weight.

\begin{tabular}{lccccc} 
& \multicolumn{3}{c}{$\begin{array}{c}\text { Custome Proces } \\
\text { Financial }\end{array}$} & $\begin{array}{l}\text { Learning } \\
\text { Alternative } \\
\text { priority } \\
\text { weight }\end{array}$ \\
\cline { 1 - 4 } Weight & 0.23 & 0.39 & 0.19 & 0.19 & \\
\cline { 1 - 4 } Alternatives & & & & & \\
SBU A & 0.475 & 0.378 & 0.45 & 0.4004 & 0.42 \\
SBU B & 0.3384 & 0.378 & 0.22 & 0.4412 & 0.35 \\
SBU C & 0.1866 & 0.244 & 0.33 & 0.1484 & 0.23
\end{tabular}


The priority weights for the alternatives were found to be $(0.42,0.35,0.23)$. According to the final result, SBU A is the most preferred SBU because it has the highest priority weight and SBU B is the next recommended SBU.

\section{Conclusion}

This study proposed a novel model for innovative assessment of SBUs and determined its applicability into a steel manufacturing holding. For this, the main literature of R\&D, innovation, BSC and performance measurement of innovation, as well as those previous studies that have dealt with the problem of measuring innovation, have been reviewed. Based on literature review and the opinion of experts, a BSC model for innovation performance assessment has been developed. This model was composed by the four perspectives and thirteen criteria. Selection of the most innovative SBU was a comparison of units using a common set of criteria and indicators to identify unit with the highest innovation performance. In this study, a fuzzy AHP method was used to select the most innovative SBU. Then, the weights of the BSC dimensions, criteria, and alternatives were determined and the best SBU was selected after computing the overall score of each unit.

Selecting the high performance unit extremely increased the competitiveness among SBUs and improved corporation competitiveness. Additionally, SBU ranking regards innovation performance could serve as input to shape award allocation, budget plan modification, and incentive plans.

Some distinguished contributions of this research are as follows:

1. This research adopted the concept of the BSC to develop an innovation evaluation structure for SBUs in a steel manufacturing company. Based on literature review and interview with experts, thirteen innovation performance indicators for SBUs were finalized. These indicators could be a reference for steel industry for innovation performance evaluation.

2. This research is based on the fuzzy set theory and the fuzzy AHP to propose a systematic performance evaluation model and to provide guidance to innovation managers for improving SBU performance.

There are many other methods to use in comparing SBUs. As for future work, other fuzzy MCDM approaches like fuzzy Dematel, fuzzy TOPSIS, or fuzzy ELECTRE could be used for SBU selection and could be compared with the current study finding.

\section{References}

ALEGRE, J., CHIVA, R., \& LAPIEDRA, R. 2009. Measuring innovation in long product development cycle industries: an insight in biotechnology. echnology Analysis \& Strategic Management, 21, 535-546.

AMIRAN, H., RADFAR, I., \& ZOLFANI, S.H. A fuzzy MCDM approach for evaluating steel industry performance based on balanced scorecard: A case in Iran. 2nd 
IEEE International Conference on Emergency Management and Management Sciences (ICEMMS) 2011. IEEE, 574-577.

BENTES, A. V., CARNEIRO, J., DA SILVA, J. F., \& KIMURA, H. 2012. Multidimensional assessment of organizational performance: Integrating BSC and AHP. Journal of Business Research, 65, 1790-1799.

BIGLIARDI, B., \& DORMIO, A.I. 2010. A balanced scorecard approach for R\&D: evidence from a case study Facilities. 28, 278-289.

BÜYÜKÖZKAN, G., ÇIFÇI, G., \& GÜLERYÜZ, S. 2011. Strategic analysis of healthcare service quality using fuzzy AHP methodology. Expert Systems with Applications, 38, 9407-9424.

CEBECI, U. 2009. Fuzzy AHP-based decision support system for selecting ERP systems in textile industry by using balanced scorecard. Expert Systems with Applications, 36, 8900-8909.

CEBECI, U., SEZEREL, B. 2008. Performance evaluation model for R\&D department: An integrated balanced scorecard and analytical hierarchy process approach. 3rd International Conference on Intelligent System and Knowledge Engineering, 1, 1276-1281.

CHAN, F. T. S., \& KUMAR, N. 2007. Global supplier development considering risk factors using fuzzy extended AHP-based approach. Omega, $35417-43.1$

CHAN, V., MUSSO, C., \& SHANKAR, V. 2008. Assessing innovation metrics. McKinsey Quarterly, Oct.

CHAN, Y. L. 2006. An Analytic Hierarchy Framework for Evaluating Balanced Scorecards of Healthcare Organizations. Canadian Journal of Administrative Sciences, 23, 85-104.

CHANG, D.-Y. 1992. Extent analysis and synthetic decision. Optimization Techniques and Applications, 1, 352-355.

CHANG, D.-Y. 1996. Applications of the extent analysis method on fuzzy AHP. European journal of operational research, 95, 649-655.

CHEN, C., \& CHEN, P. 2009. An evaluation of innovation performance based on fuzzy interval linguistic variables. Journal of the Chinese Institute of Industrial Engineers, 26, 387-396.

CHO, C. \& LEE, S. 2011. A study on process evaluation and selection model for business process management. Expert Systems with Applications, 38, 63396350.

CHO, D. W., LEE, Y.H., AHN, S.H., \& HWANG, M.K. 2012. A framework for measuring the performance of service supply chain management. Computers \& Industrial Engineering 62, 801-812.

DAMANPOUR, F. 1991. Organizational innovation: A meta-analysis of effects of determinants and moderators. Academy of management journal, 34, 555-590.

DE VEN, V. \& H., A. 1986. Central problems in the management of innovation. Management science, 32, 590-607.

DERVITSIOTIS, K. N. 2010. A framework for the assessment of an organisation's innovation excellence. Total Quality Management \& Business Excellence, 21, 903-918. 
GRIGOROUDIS, E., ORFANOUDAKI, E., \& ZOPOUNIDIS, C. 2012. Strategic performance measurement in a health care organisation: A multiple criteria approach based on balanced scorecard. Omega, 40, 104-119.

HAGHIGHI, M., DIVANDARI, A. \& KEIMASI, M. 2010. The impact of 3D e-readiness on e-banking development in Iran: A fuzzy AHP analysis. Expert Systems with Applications, 37, 4084-4093.

HAMEL, G. 2006. The Why, What, and How of Management Innovation. Harvard Business Review, 84, 72.

HAN, J., KIM, N. \& SRIVASTAVA, R. 1998. Market orientation and organizational performance: is innovation a missing link? The Journal of marketing, 62, 3045.

HUANG, H. C. 2009. Designing a knowledge-based system for strategic planning: a balanced scorecard perspective. Expert Systems with Applications, 36, 209218.

HUANG, H. C., LAI, M.C., \& LIN, L.H. 2011 .Developing strategic measurement and improvement for the biopharmaceutical firm: Using the BSC hierarchy. Expert Systems with Applications, 38, 4875-4881.

HULT, G., HURLEY, R. \& KNIGHT, G. 2004. Innovativeness: its antecedents and impact on business performance. Industrial marketing management, 33, 429438.

JOVANOVIC, J., \& KRIVOKAPIC, Z. 2008. AHP in implementation of Balanced Scorecard. International Journal of Quality Research, 2, 59-67.

KAHRAMAN, C., CEBECI, U., \& RUAN, D. 2004. Multi-attribute comparison ofcatering service companies using fuzzy AHP: The case of Turkey. International Journal of Production Economics, 87, 171-184.

KAPLAN, R. S., \& NORTON, D.P. 1992 The balance scorecard - Measures that drive performance. Harvard Business Review, 70, 71-79.

KAPLAN, R. S., \& NORTON, D.P. 1993. Putting the balanced scorecard to work. Harvard Business Review, 71, 134-140.

KAPLAN, R. S., \& NORTON, D.P. 1996. Using the balance scorecard as a strategic management system. Harvard Business Review, 74, 75-85.

KILINCCI, O., \& ONAL, S.A. 2011. Fuzzy AHP approach for supplier selection in a washing machine company. Expert Systems with Applications, 38, 96569664.

KUNZ, H., \& SCHAAF, T. 2011. General and specific formalization approach for a Balanced Scorecard: An expert system with application in health care. Expert Systems with Applications, 38, 1947-1955.

KUTLU, A. C. E. L., M. 2012. Fuzzy failure modes and effects analysis by using fuzzy TOPSIS-based fuzzy AHP. Expert Systems with Applications, 39, 6167.

KWONG ,C. K., \& BAI, H. 2003. Determining the importance weights for the customer requirements in QFD using a fuzzy AHP with an extent analysis approch. IEE Transactions, 35, 619-626. 
LAZZAROTTI, V., MANZINI, R., \& MARI, L. 2011. A model for R\&D performance measurement. International Journal of Production Economics, 134, 212-223.

LEE, A. H. I., CHEN, W., \& CHANG, C.J. 2008. A fuzzy AHP and BSC approach for evaluating performance of IT department in the manufacturing industry in Taiwan. Expert Systems with Applications, 34, 96-107.

LEUNG, L., LAM, K., \& CAO, D. 2006. Implementing the Balanced Scorecard using the Analytic Hierarchy Process and the Analytic Network Process. Journal of the Operational Research Society, 57, 682-691.

OECD 1994. Main Definitions and Conventions for the Measurement of Research and Experimental Development. A Summary of the Frascati Manual. París: OCDE/GD. 94.

REISINGER, H., CRAVENS, K.S., \& TELL, N. 2003. Prioritizing performance measures within the balanced scorecard framework. Management International Review, 43, 429-437.

SANDSTROM, J., \& TOIVANEN, J. 2002. The problem of managing product development engineers: Can the balanced scorecard be an answer? International Journal of Production Economics, 78, 79-90.

SEARCY, D. L. 2004. Aligning the Balanced Scorecard and a Firm's Strategy Using the Analytic Hierarchy Process. Management Accounting Quarterly, 5.

SHARMA, M., \& BHAGWAT, R. 2007. An integrated BSC-AHP approach for supply chain management evaluation. Measuring Business Excellence. 11, 57-68.

SU, C. H., HUNG, Y.H., \& TZENG, G.H. 2011. Fuzzy multiple attribute decision making theory with the balanced scorecard application in mobile industry. IEEE International Conference on Fuzzy Systems DOI: 10.1109/FUZZY.2011.6007558.

TANG, Y.-C \& .BEYNON, M. J. 2005. Application and development of a fuzzy analytic hierarchy process within a capital investment study. Journal of Economics and Management, 1, 207-230.

VALDERRAMA, T. G., MENDIGORRI, E.M., \& BORDOY, D.R. 2009. Relating the perspectives of the balanced scorecard for R\&D by means of DEA. European Journal of Operational Research, 196, 1177-1189.

VANDAELE, N. J., \& DECOUTTERE, C.J. 2013. Sustainable R\&D portfolio assessment. Decision Support Systems, 54, 1521-1532.

VARMA, S., WADHWA, S \& ,.DESHMUKH, S.G. 2008. Evaluation petroleum supply chain performance: application of Analytical Hierarchy Process to Balanced Scorecard. Asian Pacific Journal of Mark Logistics, 20, 343-356.

WANG, J., LIN, W., \& HUANG, Y. 2010. A performance-oriented risk management framework for innovative R\&D projects. Technovation, 30, 601-611.

WANG, L., ZHANG, H., \& ZENG, Y.R. 2012. Fuzzy analytic hierarchy process (FAHP) and balanced scorecard approach for evaluating performance of Third-Party Logistics (TPL) enterprises in Chinese context. African Journal of Business Management, 6, 521-529.

WANG, Y., \& XIA, Q. A fuzzy AHP and BSC approach for evaluating performance of a software company based on knowledge management. 1st International 
Conference on Information Science and Engineering (ICISE), 2009. IEEE, 2242-2245.

WU, H. Y., TZENG, G.H., \& CHEN, Y.H. 2009. A fuzzy MCDM approach for evaluating banking performance based on Balanced Scorecard. Expert Systems with Applications, 36, 10135-10147.

ZHU, Y., \& LEI, H. 2012 .Fuzzy AHP Analysis on Enterprises' Independent Innovation Capability Evaluation. Physics Procedia, 24, 1285-1291. 